\title{
STUDIES ON BLOOD COAGULATION : A PROTEOLYTIC ENZYME PREPARED FROM CALCIUM AND PLATELET FREE NORMAL HUMAN BLOOD PLASMA ${ }^{1}$
}

\author{
By HENRY J. TAGNON,2 CHARLES S. DAVIDSON, AND F. H. L. TAYLOR \\ (From the Thorndike Memorial Laboratory, Second and Fourth Medical Services (Harvard), \\ Boston City Hospital, and the Department of Medicine, Harvard Medical School, Boston)
}

(Received for publication March 31, 1942)

The concept that blood plasma may contain a proteolytic enzyme system associated with blood coagulation is not new. Evidence has been accumulating from investigations in unrelated fields which points to the existence of such a system. but precise experimental evidence is lacking. The literature on fibrinolysis, considered as a problem related to blood coagulation, has been reviewed by Nolf (1), Hougardy (2) and Tagnon (3). Nolf reported observations on the fibrinolytic properties of serum obtained by shaking recalcified plasma with chloroform. He considers the enzyme responsible for this phenomenon to be an important factor in blood coagulation. Barker (4) in 1908 reported that fibrin contained a proteolytic enzyme system and explained his obșervations on the basis of entrapped mononuclear cells in the fibrin. Jobling and Petersen (5) published a series of articles in 1914 on the nature of serum antitrypsin. They found that when serum was treated with chloroform, ether, and other organic solvents, the antitrypsin was removed. They failed, however, to demonstrate any tryptic activity in the treated serum. Minot (6) investigated the clotting activity of chloroform on oxalated blood and reported that the chloroform removed antithrombin from the serum. Yamakawa (7) in 1918 studied the effect of ether, chloroform, and adsorption on serum and was able to obtain some proteolytic effects. He suggested that the effects of the reagents used depended upon the removal of an antitryptic substance.

1 The expenses of this investigation were defrayed in part by a gift to Harvard University from the Smith, Kline and French Laboratories, Philadelphia, Pennsylvania; and in part by a grant given "in recognition of Dr. Francis W. Peabody's services to the Foundation" by the Ella Sachs Plotz Foundation.

2 Graduate Fellow, Belgian American Educational Foundation, 1941-1942.
The subject of the effect of proteolytic enzyme systems, not of plasma origin, on blood plasma and fibrinogen has been reviewed by, and reinvestigated in, the work of Eagle (8) who showed that trypsin itself could cause blood coagulation. Eagle has suggested a coagulation reaction based on the Howell theory, in which calcium ion, blood platelets, or thromboplastin are replaced by trypsin. Ferguson and his coworkers $(9,10)$ have proposed a thromboplastic enzyme system, capable of breaking certain plasma complexes, which they consider related to blood coagulation. Until rerently, however, the demonstration of the presence of a tryptic-like enzyme in plasma has been lacking.

Nolf (1) found that chloroform treated recalcified plasma possessed marked coagulation and fibrinolytic effect. Tagnon $(3,11)$, working exclusively on dog blood and using fibrinogen solution for testing purposes, repeated Nolf's observations and showed that when suitable concentrations of dog plasma preparations were used, the fibrin clot which first formed was redissolved. With still higher concentrations, no coagulation took place but fibrinogen was destroyed as evidenced by failure of the solution to clot when thrombin was subsequently added.

For purposes of purification, Tagnon precipitated diluted chloroform treated plasma at $\mathrm{pH} 6$ and found that the precipitate contained essentially all of the activity of the preparation. $\mathrm{He}$ also showed that when the euglobulin fraction of this preparation was separated by dialysis, this fraction also contained most of the activity of the preparation.

Tagnon pointed out the similarity of action between his preparation and the action of trypsin on blood coagulation as described by Eagle (8). Apparently chloroform treated plasma was able, like trypsin, to produce thrombin from prothrom- 
bin. Like trypsin also, was the failure of the chloroform treated plasma to coagulate fibrinogen unless prothrombin were present. The lytic effect of chloroform plasma on fibrinogen was also analagous to trypsin.

These observations have been confirmed in this laboratory. The present communication is an attempt to extend Tagnon's investigations to plasma of other species, to present further developments in preparation, and to present preliminary evidence that such preparations of plasma may constitute part of a plasma enzyme system. Investigations have shown that a non-cellular fraction of the plasma euglobulin has a rôle in blood coagulation independent of prothrombin and fibrinogen $(12,13)$. Therefore, the present observations also demonstrate the rôle which this "globulin substance" may play in a plasma enzyme system associated with blood coagulation. Lastly, the investigations attempt to show whether calcium ion or platelets are necessary in the elaboration of an active preparation. In the accompanying communication (14), the nature of the active agent will be discussed.

\section{EXPERIMENTAL}

\section{Methods}

Normal human blood was collected in sufficient 2.5 per cent sodium citrate to give a final concentration of 0.25 per cent of this salt. ${ }^{3}$ The plasma was obtained by centrifuging. Platelets and other formed elements were removed by recentrifuging the plasma at 4200 revolutions per minute for 30 minutes. To each $100 \mathrm{ml}$. of fresh cell free citrated plasma, $10 \mathrm{ml}$. of chloroform were added, without recalcification, and the mixture shaken vigorously for 1 minute in a tightly closed flask. It is important that the plasma be treated with chloroform within 12 hours of venepuncture. After some hours, a clot formed with considerable imbibition of the fluid portion of the mixture. The preparations were allowed to stand at room temperature, in the closed containers, until all of the clot had disappeared. This reaction for normal human plasma usually was complete in from 3 to 8 days. Rarely, a longer period than 8 days was required. When all the clot had disappeared, the flasks were opened and samples removed for bacteriological examination. The preparations were tested for prothrombin by recalcification or by Quick's procedure (15) after the addition of fibrinogen, and for fibrinogen by the addition of thrombin.

$\mathbf{8}$ In many experiments, the citrate was replaced by oxalate $(0.1 \mathrm{ml}$. of a saturated solution of potassium oxalate to each $10 \mathrm{ml}$. of blood) without altering the results in any way.
Both of these substances were absent. In no instance was the presence of bacteria, either by direct smear or by aerobic culture, demonstrated. The chloroform was removed by centrifuging and evaporation by a current of air. From this point on, any one of three methods of purification and concentration was employed. (1) The contents of the flasks were diluted with 10 volumes of distilled water, and the acidity brought to $\mathrm{pH} 6$ by the addition of 1 per cent acetic acid. The supernatant liquid was syphoned off and the last portion of it removed by centrifuging. The precipitate was dissolved in 0.9 per cent sodium chloride to make a solution one-tenth the original volume of plasma. (2) Otherwise, the contents of the reaction flasks were transferred to cellophane tubes and dialyzed against running tap water at $8^{\circ} \mathrm{C}$. for 3 or 4 days. The euglobulin precipitate so formed was separated from the supernatant liquid by centrifuging, and then dissolved in 0.9 per cent sodium chloride solution to make one-tenth the original volume of plasma. (3) To avoid dilution of the chloroform treated plasma and to shorten the time of dialysis, a third modification was occasionally employed, which was essentially a combination of the first two methods. The chloroform treated plasma was dialyzed for one and a half days and then, without dilution, the contents of the cellophane sacks were adjusted to $\mathrm{pH} 6$. The resulting precipitate was again dissolved in an amount of 0.9 per cent sodium chloride solution equal to one-tenth the original volume of the plasma. This saline solution of the active material will be referred to as "chloroform plasma globulin solution." Modifications of the above standard procedures were sometimes employed for special purposes. These will be outlined at the appropriate time.

Fibrinogen was prepared by the method of Mellanby (16). Prothrombin was prepared by a modification of the method of Mellanby (16) in which diluted oxalated plasma was deprived of its fibrinogen by rapid heating to $56^{\circ} \mathrm{C}$., cooling, and removal of the precipitate by filtration. The filtrate was brought to $\mathrm{pH} 5.3$ by 1 per cent acetic acid, and the precipitate so formed dissolved in one-tenth the original plasma volume with 0.9 per cent sodium chloride solution. Both fibrinogen and prothrombin preparations were kept by rapid freezing to minus $45^{\circ}$ C. and storing in a carbon dioxide refrigerator at that temperature. Thrombin 4 was prepared from rabbit plasma by the method of Parfentjev $(17,18)$. Globulin substance was prepared either by acid precipitation (19) or by dialysis (2).

Titration of the activity of preparations and observations on fibrinolysis were made by placing $0.1 \mathrm{ml}$. of plasma or fibrinogen solution in $156 \times 13 \mathrm{~mm}$. test tubes, adding the requisite amount of the preparation to be studied and diluting the mixture to a total volume of 1.0 ml. with 0.95 per cent salt solution or imidazole buffer (20) at $\mathrm{pH} 7.4$. All reagents and preparations used were adjusted to $\mathrm{pH}$ 7.4. All observations were made at $37.5^{\circ}$ C. in a constant temperature water bath.

4 Supplied by Lederle Laboratories, Inc., Pearl River, New Jersey. 
GENERAL PROPERTIES OF CHLOROFORM PLASMA GLOBULIN SUBSTANCE

Action of chloroform plasma globulin solution on fibrinogen solution

- Tagnon showed that the addition of increasing amounts of his dog blood preparation to fibrinogen solution was not accompanied by clot formation. However, when a sufficient quantity was added, fibrinogen was completely destroyed, as indicated by the failure of thrombin to produce a fibrin clot. In a few preparations, we were able to obtain such a result. In most instances, however, coagulation of the fibrinogen occurred. This was considered to be due to small amounts of thrombic activity remaining in the preparation. It could be demonstrated that the lytic activity of the chloroform preparation was not due to its thrombin content, as shown below. peated using pure thrombin solutions, clot formation occurred at all concentrations employed, but no lytic action was observed during a subsequent period of 24 hours. Seegers (21) likewise has failed to show any fibrinolytic property in his thrombin preparation.

\section{Action of chloroform plasma globulin solution on normal plasma}

When the smallest quantity of chloroform plasma preparation which completely lysed fibrinogen, and which failed to clot fibrinogen solutions, was added to $0.1 \mathrm{ml}$. of plasma under standard conditions, a clot always occurred. Furthermore, much higher concentrations of the preparation could be added to plasma before clot formation was prevented. This is shown in the lower half of Table I. The sequence of events when

TABLE I

Activity of a chloroform globulin preparation on plasma and fibrinogen

\begin{tabular}{|c|c|c|c|c|c|c|}
\hline $\begin{array}{l}\text { Chloroform } \\
\text { globulin } \\
\text { preparation }\end{array}$ & $\begin{array}{l}\text { Oxalated } \\
\text { steer } \\
\text { plasma }\end{array}$ & $\begin{array}{l}\text { Oxalated } \\
\text { fibrinogen }\end{array}$ & Saline & Clot formation & Dissolution & $\begin{array}{l}\text { Thrombin } \\
\text { solution after } \\
30 \text { minutes }\end{array}$ \\
\hline $\begin{array}{l}m l . \\
0.0 \\
0.1 \\
0.3 \\
0.8\end{array}$ & $m l$. & $\begin{array}{l}m l . \\
0.2 \\
0.2 \\
0.2 \\
0.2\end{array}$ & $\begin{array}{l}m l . \\
0.8 \\
0.7 \\
0.5 \\
0.0\end{array}$ & $\begin{array}{l}\text { No clot } 30 \text { minutes } \\
\text { Clot } 2 \text { minutes } \\
\text { No clot } 30 \text { minutes } \\
\text { No clot } 30 \text { minutes }\end{array}$ & Dissolved $10 \frac{1}{2}$ minutes & $\begin{array}{l}\text { Clot } \\
\text { No clot } \\
\text { No clot } \\
\text { No clot }\end{array}$ \\
\hline $\begin{array}{l}0.0 \\
0.1 \\
0.3 \\
0.9\end{array}$ & $\begin{array}{l}0.1 \\
0.1 \\
0.1 \\
0.1\end{array}$ & & $\begin{array}{l}0.9 \\
0.8 \\
0.6 \\
0.0\end{array}$ & $\begin{array}{l}\text { No clot } 30 \text { minutes } \\
\text { Clot } 1 \frac{1}{2} \text { minutes } \\
\text { Clot } 1 \frac{1}{2} \text { minutes } \\
\text { No clot } 30 \text { minutes }\end{array}$ & $\begin{array}{l}\text { Not dissolved } 30 \text { minutes } \\
\text { Dissolved } 12 \text { minutes }\end{array}$ & $\begin{array}{l}\text { Clot } \\
\text { No clot } \\
\text { No clot }\end{array}$ \\
\hline
\end{tabular}

As shown in the upper part of Table I, when increasing amounts of the chloroform plasma globulin preparation were added to a fibrinogen solution, coagulation occurred only in the lower concentration. In all instances, a point was reached at which no coagulation occurred. Fibrinogen had been completely destroyed by the activity of the preparation. Furthermore, with increasing concentration of the chloroform plasma globulin, increasing lysis of the fibrin clot occurred. It could be concluded, therefore, that the preparation contained, in addition to thrombin, a powerful lytic material. When chloroform plasma globulin solutions were prepared according to the standard procedure in one-tenth the original volume of plasma, these results could aiways be duplicated. When these observations were re- plasma was used instead of fibrinogen solutions is clearly indicated in Table I. With increasing concentration of the chloroform plasma preparation, there was coagulation followed by increased fibrinolysis until finally no coagulation occurred and no fibrinogen was present, as tested by the addition of thrombin. That the failure of the fibrinogen solution to clot after the addition of the chloroform preparation was not due to any antithrombic action of the preparation was demonstrated by the failure to obtain fibrinogen by chemical methods, when thrombin failed to coagulate the fibrinogen solution. The results would indicate that there was a marked inhibition of the lytic effect of chloroform plasma globulin preparation by plasma. What fraction of the plasma constituents is responsible for this inhibition is not 
TABLE II

Action of prothrombin on the activity of a chloroform globulin preparation

\begin{tabular}{|c|c|c|c|c|c|c|}
\hline $\begin{array}{l}\text { Chloroform } \\
\text { globulin } \\
\text { preparation }\end{array}$ & $\begin{array}{c}\text { Oxalated } \\
\text { fibrinogen }\end{array}$ & Saline & $\begin{array}{c}\text { Oxalated } \\
\text { pro- } \\
\text { thrombin }\end{array}$ & Clot formation & Dissolution & $\begin{array}{l}\text { Thrombin } \\
\text { solution after } \\
30 \text { minutes }\end{array}$ \\
\hline $\begin{array}{l}m l . \\
0.0 \\
0.1 \\
0.3\end{array}$ & $\begin{array}{l}m l . \\
0.2 \\
0.2 \\
0.2\end{array}$ & $\begin{array}{l}m l . \\
0.8 \\
0.7 \\
0.5\end{array}$ & $\begin{array}{l}m l . \\
0 \\
0 \\
0\end{array}$ & $\begin{array}{l}\text { No clot } 30 \text { minutes } \\
\text { Clot } 2 \text { minutes } \\
\text { No clot } 30 \text { minutes }\end{array}$ & Dissolved $1 \frac{1}{2}$ minutes & $\begin{array}{l}\text { Clot } \\
\text { No clot } \\
\text { No clot }\end{array}$ \\
\hline $\begin{array}{l}0.3 \\
0.3 \\
0.3\end{array}$ & $\begin{array}{l}0.2 \\
0.2 \\
0.2\end{array}$ & $\begin{array}{l}0.4 \\
0.4 \\
0.4\end{array}$ & $\begin{array}{l}0.03 \\
0.1 \\
0.3\end{array}$ & $\begin{array}{l}\text { Clot } 1 \frac{1}{2} \text { minutes } \\
\text { Clot } 1 \frac{1}{2} \text { minutes } \\
\text { Clot } 1 \frac{1}{2} \text { minutes }\end{array}$ & $\begin{array}{l}\text { Dissolved } 15 \text { minutes } \\
\text { Not dissolved } 30 \text { minutes } \\
\text { Not dissolved } 30 \text { minutes }\end{array}$ & No clot \\
\hline
\end{tabular}

definitely established. It is known, however, that a plasma preparation containing a high concentration of prothrombin activity (17) will, as shown in Table II, reduce the lytic action of chloroform plasma to the same extent as plasma itself. This might suggest that prothrombin itself could be the inhibitor.

\section{THE RELATIONSHIP OF CHLOROFORM PLASMA GLOBULIN TO "GLOBULIN SUBSTANCE"} AND PLASMA EUGLOBULIN

Previous reports from this laboratory $(12,13)$ have shown the specific relationship of a globulin fraction of normal cell free plasma to the coagulation of blood. Tagnon has pointed out (11) that in the purification of his chloroform preparations and dialysis (13) for the latter preparation. While it is known that both of these preparations have a marked effect in promoting the coagulation of hemophilic blood, they have no fibrinolytic power. Isotonic saline solutions of globulin substance or plasma euglobulin were treated with chloroform and permitted to stand at room temperature until the clot which had formed disappeared. The mixture was freed from chloroform and then was either precipitated at $\mathrm{pH} 6$ or dialyzed against tap water at $10^{\circ} \mathrm{C}$. in cellophane bags. In either case, the precipitate was dissolved in 0.9 per cent sodium chloride solution. Unlike the parent globulin substance or euglobulin, the preparation had marked fibrinolytic and fibrinogenolytic activity as shown in Table III. These results show that while globulin substance and plasma euglobu-

TABLE III

The activity of a preparation derived from chloroform treated globulin substance

\begin{tabular}{|c|c|c|c|c|c|c|}
\hline $\begin{array}{l}\text { Active preparation } \\
\text { from } \\
\text { globulin substance }\end{array}$ & Saline & $\begin{array}{c}\text { Oxalated } \\
\text { fibrinogen }\end{array}$ & $\begin{array}{c}\text { Oxalated } \\
\text { plasma }\end{array}$ & Clot formation & Dissolution & $\begin{array}{l}\text { Thrombin } \\
\text { added after } \\
30 \text { minutes }\end{array}$ \\
\hline $\begin{array}{l}m l . \\
0 \\
0.1 \\
0.3 \\
0.5\end{array}$ & $\begin{array}{l}m l . \\
0.9 \\
0.8 \\
0.6 \\
0.4\end{array}$ & $\begin{array}{l}m l . \\
0.1 \\
0.1 \\
0.1 \\
0.1\end{array}$ & $m l$. & $\begin{array}{l}\text { No clot } \\
\text { Clot } 1 \text { minute } \\
\text { No clot } \\
\text { No clot }\end{array}$ & Dissolved 10 minutes & $\begin{array}{l}\text { Clot } \\
\text { No clot } \\
\text { No clot } \\
\text { No clot }\end{array}$ \\
\hline $\begin{array}{l}0 \\
0.1 \\
0.5 \\
0.8\end{array}$ & $\begin{array}{l}0.9 \\
0.8 \\
0.4 \\
0.1\end{array}$ & & $\begin{array}{l}0.1 \\
0.1 \\
0.1 \\
0.1\end{array}$ & $\begin{array}{l}\text { No clot } \\
\text { Clot } 1 \text { minute } \\
\text { Clot } 1 \text { minute } \\
\text { Clot } 1 \text { minute }\end{array}$ & $\begin{array}{l}\text { None } 30 \text { minutes } \\
\text { Dissolved } 20 \text { minutes } \\
\text { No clot }\end{array}$ & $\begin{array}{l}\text { Clot } \\
\text { No clot } \\
\text { No clot }\end{array}$ \\
\hline
\end{tabular}

similar methods were used to those employed in making globulin substance and plasma euglobulin preparation. He suggested that there might be a relationship between these two substances. GloBulin substance and plasma euglobulin were prepared by acid precipitation (20) for the former lin are essentially inactive as enzymes, they can readily be converted, without the addition of calcium, to proteolytically active substances by simple treatment with chloroform. The supernatant liquid, after removal of plasma euglobulin by dialysis, is not a potent source of enzyme. 


\section{THE EFFECT OF CALCIUM ION AND PLATELETS}

In Tagnon's original preparation, the dog's plasma was recalcified before chloroform was added. It could be, therefore, contended that calcium was a possible reactant in the reaction he described. Similarly, the possibility of the presence of platelets in the plasma was not ruled out, and it might be argued by those adhering to the generally accepted theory of blood coagulation that thromboplastin of platelet origin was also involved. In the present studies, calcium ion was either removed by oxalate ion or rendered inactive by the presence of citrate ion; yet the reaction proceeded in the absence of that ion. To explore these facts further, many comparisons of fibrinolytic activity were made between recalcified and calcium ion free plasma, and platelet free and platelet rich plasma. $^{5}$ No essential differences could be detected. It was, therefore, considered that this new enzyme system could be prepared from substances present in cell free plasma without the intervention of calcium ion. It was also considered that the proteolytic enzyme could be elaborated from some non-cellular plasma derivatives, such as either globulin substance or some substance associated with the plasma euglobulin.

The data of Table I also show a thrombic activity to be present in the preparation although platelets were removed and calcium ion absent. Further evidence was obtained by a study of the blood plasma enzyme obtained from a patient with thrombocytopenic purpura. Although the blood platelet count was only 2,000 per c.mm., the plasma enzyme was found in normal amounts.

Active enzyme preparations were also made by treating the portion of the plasma proteins precipitated between 20 per cent and 40 per cent saturation with ammonium sulphate, with chloroform and subsequently dialyzing in cellophane sacks.

\section{DISCUSSION}

The data presented indicate that when platelet free normal human plasma, free from active calcium ion, is treated with chloroform, a fraction of the plasma globulins appears to be changed or modified so that it exhibits the property of an

\footnotetext{
5 Platelet rich plasma was obtained by adding to normal plasma the platelet suspension obtained when platelet free plasma was prepared.
}

enzyme. This enzyme appears to have the property of lysing both fibrin and fibrinogen. The enzyme preparations contain neither prothrombin nor fibrinogen.

Tagnon (3) has shown that similar preparations made from recalcified dog's plasma had similar properties. $\mathrm{He}$ also showed that these preparations were able to transform prothrombin into thrombin without the presence of calcium. The presence of thrombic activity in most of our preparations from normal human plasma indicates that a similar transformation of prothrombin occurs. This concept is supported by the fact that chloroform plasma globulin preparations can coagulate solutions of fibrinogen. The presence of thrombic activity in a preparation from plasma containing no active calcium ion is interesting. This represents the second type of preparation from plasma in which such a situation has arisen. Parfentjev (17) described a pseudoglobulin fraction prepared from citrated or oxalated rabbit plasma, having a clot promoting activity. We were able to repeat these observations and also were able to prove the activity thrombic in nature (19). In these preparations, calcium ion was removed by addition of oxalate or citrate.

There is a marked difference, however, between the chloroform plasma globulin preparation and thrombin prepared by Parfentjev's procedure. The first has the power to clot oxalated plasma and fibrinogen solution and then rapidly to lyse the precipitated fibrin. Parfentjev's thrombin will coagulate fibrinogen instantly, but at no concentration will fibrinolysis occur, within the observation period of 24 hours.

Tagnon, using dog blood as a source of enzyme, stated that his preparation coagulated plasma, but not fibrinogen solution unless prothrombin were added. Using human blood, the chloroform preparation nearly always exhibited a slight thrombic activity. We have, however, by careful quantitation been able to find for all our preparations some concentration at which fibrinogenolysis occurs before coagulation by the thrombic activity can intervene. In both Tagnon's preparations and the present ones, thrombin always was produced as a result of chloroform action, but Tagnon was able to destroy the thrombic activity of his preparation by allowing the preparation to 
stand, while we were unable to remove the last traces of it in our preparation by this method.

So far as the experiments on fibrinogen are concerned, we must for the present report that, dependent upon the concentration used, the following events occur. At low concentration of the chloroform plasma globulin, coagulation of fibrinogen occurs, while at higher concentration, the coagulation is followed by fibrinolysis, and at still higher concentrations, fibrinogenolysis occurs with no coagulation. The absence of fibrinogen can be demonstrated either by the addition of thrombin or by failure to obtain fibrinogen by heating or salting out methods.

Plasma and derivatives of plasma containing a high concentration of prothrombin definitely inhibit the proteolytic activity of the chloroform plasma preparation. This is indicated by the much higher concentration of the preparation required to effect lysis of the clot, and the still higher concentration required to remove fibrinogen by lysis prior to coagulation. The nature of this inhibition is under investigation at present. Jobling's experiments (5) on trypsin are of interest in this regard. This author concluded that an antitryptic material was removed from plasma by the action of chloroform. Unfortunately, his experiments do not preclude the possibility of augmentation of tryptic effect due to the elaboration of another but similar proteolytic enzyme by the action of chloroform on the plasma.

Fibrinolysis does occur in certain disease states subsequent to the coagulation of shed blood. Such instances, however, are rare except when bacterial contamination of the blood is present. Furthermore, the time required for such fibrinolysis is very long. In the present investigation, all preparations were made under sterile conditions and no bacterial contamination was found at the end of the incubation period. It is concluded, therefore, that the proteolytic activity was elaborated as a result of the chloroform treatment.

The inactive progenitor of the fibrinolytic factor present in plasma is uncertain. It can be stated, however, that the impure protein fraction, contained in globulin substance which has no proteolytic activity, can be activated by chloroform. The proteolytic activity of such a preparation is in no wise different from that obtained from whole plasma. Similarly, plasma euglobulin, equally in- active as a proteolytic enzyme, can be activated by chloroform to develop marked fibrinolytic action. The supernatant liquid from the euglobulin preparation is not a source of significant amounts of the enzyme.

There has been, up to the present time, no indication of general species specificity. The proteolytic activity is present in chloroform plasma globulin preparations of human, dog, beef, rabbit, and swine blood. Horse blood is an exception insofar as preparations from such blood are only minimally potent.

In many respects, the chloroform plasma preparation, as reported here and earlier by Tagnon, resembles trypsin in its action on plasma, fibrinogen, and prothrombin. The rôle which chloroform plasma globulin plays in blood coagulation is not as yet clear. However, there is no doubt that the preparation can cause coagulation of oxalated blood and fibrinogen solution, with subsequent lysis.

\section{SUM MARY}

1. A method for preparing an active enzyme from blood plasma is given.

2. In higher concentrations, the enzyme can cause both fibrinogenolysis and fibrinolysis, in both plasma and pure fibrinogen solution.

3. Plasma preparations containing high concentrations of prothrombin inhibit the enzymatic activity.

4. Globulin substance and plasma euglobulin, which possess no proteolytic activity, can be converted into globulin fractions, possessing marked proteolytic activity, by the action of chloroform.

5. Removal of calcium and platelets has no demonstrable effect on the activity of the plasma enzyme.

\section{BIBLIOGRAPHY}

1. Nolf, P., Contribution à l'étude de la coagulation du sang. 5e mémoire. La fibrinolyse. Arch. Internat. de Physiol., 1908, 6, 306.

2. Hougardy, A., La fibrinolyse. Arch. Internat. de Physiol., 1933, 36, 92.

3. Tagnon, H. J., The significance of fibrinolysis in the phenomenon of coagulation of blood. J. Lab. and Clin. Med., 1942, 27, 1119.

4. Barker, B., The enzymes of fibrin. J. Exper. Med., 1908, 10, 343.

5. Jobling, J. W., and Petersen, W., Nature of serum antitrypsin. J. Exper. Med., 1914, 19, 459. 
6. Minot, G. R., The effect of chloroform on the factors of coagulation. Am. J. Physiol., 1915, 39, 131.

7. Yamakawa, S., The autodigestion of normal serum through the action of certain chemical agents. J. Exper. Med., 1918, 27, 689.

8. Eagle, H., and Harris, T. N., Studies in blood coagulation. V. The coagulation of blood by proteolytic enzymes (trypsin, papain). J. Gen. Physiol., 1937, $20,543$.

9. Ferguson, J. H., and Erickson, B. N., Calcium and cephalin in relation to the clotting power of crystallin trypsin. Proc. Soc. Exper. Biol. and Med., 1939, 40, 625.

10. Ferguson, J. H., The clotting of hemophilic plasma by thromboplastic enzyme. Am. J. Physiol., 1939, 126, 669.

11. Tagnon, H. J., The significance of fibrinolysis in the mechanism of coagulation of blood. Science, 1942, 95, 334.

12. Lozner, E. L., and Taylor, F. H. L., The coagulation defect in hemophilia: Studies of the clot promoting activity associated with plasma euglobulin in hemophilia. J. Clin. Invest., 1939, 18, 821.

13. Lozner, E. L., Kark, R., and Taylor, F. H. L., The coagulation defect in hemophilia: The clot promoting activity in hemophilia of Berkefelded normal human plasma free from fibrinogen and prothrombin. J. Clin. Invest., 1939, 18, 603.
14. Kaplan, M. H., Tagnon, H. J., Davidson, C. S., and Taylor, F. H. L., The nature and properties of a proteolytic enzyme derived from plasma. J. Clin. Invest., 1942, 21, 533.

15. Quick, A. J., Stanley-Brown, M., and Bancroft, F. W., Study of coagulation defect in hemophilia and in jaundice. Am. J. M. Sc., 1935, 190, 501.

16. Mellanby, J., Prothrombase, its preparation and properties. Proc. Roy. Soc., s. B., London, 1930, 107, 271.

17. Parfentjev, I. A., A globulin fraction in rabbit's plasma possessing a strong clotting property. Am. J. M. Sc., 1941, 202, 578.

18. Taylor, F. H. L., Lozner, E. L., and Adams, M. A., The thrombic activity of a globulin fraction of rabbit plasma. Am. J. M. Sc., 1941, 202, 585.

19. Patek, A. J., Jr., and Taylor, F. H. L., Hemophilia. II. Some properties of a substance obtained from normal human plasma effective in accelerating the coagulation of hemophilic blood. J. Clin. Invest., 1937, 16, 113.

20. Mertz, E. T., and Owen, C. A., Imidazole buffer: Use in blood clotting studies. Proc. Soc. Exper. Biol. and Med., 1940, 43, 204.

21. Seegers, W. H., Purification of prothrombin and thrombin. J. Biol. Chem., 1940, 136, 103. 